\author{
Marquette University \\ e-Publications@Marquette
}

History Faculty Research and Publications

History, Department of

Summer 2018

\title{
My Land Is My Flesh Silver Bluff, the Creek Indians, and the Transformation of Colonized Space in Early America
}

Byron Rindfleisch

Marquette University, byron.rindfleisch@marquette.edu

Follow this and additional works at: https://epublications.marquette.edu/hist_fac

Part of the History Commons

\section{Recommended Citation}

Rindfleisch, Byron, "My Land Is My Flesh Silver Bluff, the Creek Indians, and the Transformation of Colonized Space in Early America" (2018). History Faculty Research and Publications. 274.

https://epublications.marquette.edu/hist_fac/274 


\title{
My Land Is My Flesh \\ Silver Bluff, the Creek Indians, and the Transformation of Colonized Space in Early America
}

\author{
BRYAN RINDFLEISCH \\ Marquette University
}

\begin{abstract}
This essay explores how Native peoples like the Creek (Muscogee) Indians invested colonized spaces in early American society with their own material, commercial, political, and spiritual meanings and importance. In particular, Creek Indians from the town of Coweta transformed Silver Bluff, the plantation of the trader and merchant George Galphin, into a "white ground," as a place connected to Creek Country by a "white path," and as a space where Creek and British leaders congregated to conduct business and negotiate politics. For it is no coincidence that the treaties of Augusta in 1763 and 1773, peaceful resolutions agreed to by the Creeks with the British Empire in 1760, 1764, 1773, 1774, and 1776, the negotiations over boundary lines in 1768 and 1774, and several other instances of cross-cultural dialogue all unfolded, started, or ended at Silver Bluff. The Creeks thereby enfolded occupied spaces like Silver Bluff - and the peoples who inhabited or congregated at such places - into their own worlds and according to their own understandings of those spaces. This process of spatial assimilation by the Creeks was as much collaborative as it was contested with Europeans throughout the eighteenth century.
\end{abstract}

In January 1764 Togulki-a mico from the Creek town of Cowetareceived ominous news from the east: Creek Indians, including several of

I wish to recognize the financial support of the William L. Clements Library, Newberry Library, and David Library of the American Revolution in the production of this manuscript. Different versions of this article have been presented at the American Society for Ethnohistory, the Society for Early Americanists, and the British Group of Early American Historians. Special thanks are reserved for those colleagues who have read portions of this manuscript and provided their feedback and observations-Joshua Piker, Robbie Ethridge, Andrew Frank, Kathryn Braund, Steven Hahn — and my graduate students in HIST 6110 (Spring 2017). I would also like to thank the anonymous readers who provided invaluable insight and constructive criticism for this article. This work would not have been possible without them. 
his own townspeople, killed "fourteen people, Settlers on [the] Long Canes." This conflict produced such a "Fright and Hurry" in the British colonies that "the Out Inhabitants are all flocking into the Forts," many of whom demanded the Georgia Assembly take immediate action against the Creek Nation. The unwelcome news proved especially disconcerting to Togulki, who had spent the better part of a year negotiating a treaty with Britain that brought about an end to the Seven Years' War in the South. After learning whatever "Information he could concerning the Murder of the White People," Togulki traveled east on horseback. Leaving Coweta, he traversed what was called the "Creek Path," the arterial linkage and trade route that connected Creek towns to Georgia and South Carolina. Togulki, however, did not go to any of the centers of British imperial power in the South such as Savannah, Augusta, or Charleston, as might have been expected in a time of violence that threatened to destabilize Creek-British relations. Instead, he headed for Silver Bluff, the plantation of the Indian trader and merchant George Galphin. ${ }^{1}$

There Togulki met with Galphin and told him, "As soon as I was acquainted in the Woods who the Persons were that had killed the White People I came immediately to acquaint my friend Galphin of it, that he might write down and Acquaint both Governours and the beloved Man of it, and I have left this Talk with him." Galphin then conveyed Togulki's message to the superintendent of Indian Affairs, John Stuart, and the governors of Georgia and South Carolina. In the talk Togulki stated, "The Fellows that have done the Murder are seven that have been among the Cherokees these four or five Years and helped them against the White People." Having identified the culprits, Togulki promised, "The People are all going home by the Time this Moon is gone . . . there we shall have a Meeting of all the Heads of the Nation and before the next Moon is done you shall hear from us." He then concluded, "We hope this will not make a general war if the Murderers can be killed," and asked that the path between Creek towns and the British colonies remain open. Togulki also warned the

1. John Stuart to Togulki, February 2, 1764, Thomas Gage Papers, 1754-1807, American Series, vol. 13, William L. Clements Library, University of Michigan, Ann Arbor ("fourteen"); "Lieutenant Barnard's Letter to His Excellency James Wright," December 28, 1763, Colonial Records of the State of Georgia, vol. 9, Proceedings and Minutes of the Governor and Council from January 4, 1763 to December 2, 1766, ed. Allen D. Candler (Atlanta: Franklin-Turner, 1907), 111-14 ("Fright," "flocking"); George Galphin to the Georgia Governor Wright, Council, and Assembly, January 1764, in Candler, Colonial Records of the State of Georgia, 9:114-16 ("Information"). 
English to "be upon your Guard," because, he claimed, the accused Creeks will "kill the White People where ever they find them." In a personal aside, Galphin confided to imperial officials that "he thought the Murders were not done by the lower Creeks"; he thought instead that "the Cherokees had a hand in it and perhaps some Villains of the Creeks along with them."

After transmitting Togulki's talk to the superintendent and governors, Galphin offered his plantation as a meeting place where British and Creek leaders could resolve the conflict, telling the former, "In case you should have any letters to send to the nation, there will be always some Traders at my House." He "expect[ed] Abra[ha]m [of Coweta] and some more fellows here in a few days" to join Togulki, who would "bring [another] Talk from the rest of the headmen in the Woods." Shortly thereafter, Galphin reported to imperial agents that "forty men, women, and children [are] here and I expect a great many more down," urging the governors and superintendent to make their way quickly to Silver Bluff. Meanwhile, as Britain's emissary to the Creeks, Galphin sent " 2 or 3 traders ... to look after what goods was in the [Creek] Nation" to encourage the Creeks to either hand over or execute the accused, noting, "I could not think of sending of any goods to [the] nation till I heard what the Headmen had concluded upon." As a sign of good faith, several Creek micos "left their Presents [at Galphin's] 'till they come in again."' Eventually, British authorities met with Creek headmen at Silver Bluff, and the whole affair concluded with the return of peace and trade in the region. According to European observers, further violence had been averted only by Galphin's influence as "a great favourite with most of the Creeks." ${ }^{4}$

Although Galphin and his efforts figure prominently in the drama of the

2. “Togulki's Talk Enclosed in Mr. Galphin's Letter,” January 1764, in Candler, Colonial Records of the State of Georgia, 9:114-16.

3. The title mico (headman) in Creek society referred to community leaders who negotiated on behalf of their town with other Creek micos, Native leaders, and Europeans. These individuals were almost always elders within the community, having proven themselves in combat and now assuming positions of leadership in their towns.

4. George Galphin to John Stuart, January 8, 1764, Records of the Colonial Office: Original Correspondence, Plantations General, 1689-1952, Colonial Office Series 323, Document 180 ("at my House," "Abraham," "2 or 3 traders," "concluded upon”); George Galphin to John Stuart, January 6, 1764, CO 323, Document 178 ("forty men," "Presents"); South Carolina Gazette, 1732-1775, January 7-14, 1764, MS CscG, South Caroliniana Library, University of South Carolina, Columbia ("great favourite"). 
so-called Long Canes Murders-a case that seems illustrative of the "gobetween" phenomenon prevalent in indigenous histories throughout the world - it is important to note that Togulki and other Creek micos had trekked to a specific place in British America that January. Historians often gravitate toward the individual or actor who made history, in this case Galphin, who earned praise for facilitating Creek and British negotiations. But what if we flipped the script? What if Togulki had chosen not Galphin per se but the space he occupied? It was no coincidence that Togulki made his way to Galphin's plantation rather than Charleston, Savannah, or Augusta, and this raises questions about what was so important about Silver Bluff, and whether the space was more significant than Galphin himself. Europeans in this case overwhelmingly emphasized the role of the individual. They saw Galphin as a man "possessed [of] the most extensive trade, connexions and influence, among the South and South-West Indian tribes" who had secured peace amid the violence. But for Togulki, it was more about Silver Bluff because it was a space that the Creeks had designated, conceived of, and treated as a "white ground," connected to the Creek Nation by a "white path" throughout the eighteenth century. ${ }^{5}$

In Creek cosmology, the color white represented peace and order, friendly intentions, and knowledge and wisdom; it was embodied by the micos and elders tasked with ensuring balance within the Creek Nation and associated with the Upper World to which Creek people returned after death. White's opposite, red, denoted chaos and disorder, anger and hostile intentions, and violence. Red was, moreover, often deployed in describing younger people, since "the Creeks commonly attributed violence to youth," as well as when the nation conflicted with Europeans or other indigenous peoples such as the Cherokees. The Long Canes Murders had thrown the Creeks' physical and spiritual worlds out of balance. In such times, when the red overwhelmed the white, Creek women had to step in and "whiten the red hearts" of Creek men, while male micos whitened or straightened the red and crooked paths, thereby restoring order and balance to their material and cosmological worlds. ${ }^{6}$

5. Thomas P. Slaughter, ed., William Bartram: Travels \& Other Writings (New York: Library of America, 1996), 259-61 ("connexions"); "A Treaty of Peace and Commerce Held at the Old Town," November 6, 1777, George Galphin Letters, 1777-1779, in Henry Laurens Papers, roll 17: Papers Concerning Indian Affairs, South Carolina Historical Society, Charleston ("white ground").

6. George E. Lankford, "Red and White: Some Reflections on Southeastern Symbolism," Southern Folklore 50, no. 1 (1993): 53, 55, 56, 64-65, 78; John R. Swanton, "The Green Corn Dance," Chronicles of Oklahoma 10, no. 2 (1932): 
When Creek people framed their meeting grounds or places of exchange with Europeans as white grounds, or as spaces connected by a white path to Creek Country, they imbued those places with great meaning and importance. By invoking a white ground or white path in treaty councils, trade negotiations, or everyday interactions, the Creeks linguistically and metaphorically, as well as politically and commercially, expressed a spatial reckoning of their relationships with Europeans. This understanding of space was at the heart of the Creeks' worldview, and it not only set the tone for open and peaceful interchange but also linked their physical and spiritual worlds to their relationships with Europeans. When Togulki and other micos framed Silver Bluff as a white ground or as connected to their communities by a white path, as they repeatedly did throughout the eighteenth century, they recognized a place of great significance within the Creek world.

Throughout the seventeenth and eighteenth centuries, Creek people attached many and disparate yet interrelated meanings to specific places in early America, but Silver Bluff was different. ${ }^{7}$ It had been a Native space in

194-95; Angela Pulley Hudson, Creek Paths and Federal Roads: Indians, Settlers, and Slaves and the Making of the American South (Chapel Hill: University of North Carolina Press, 2010), 11-12); Bill Granthan, Creation Myths and Legends of the Creek Indians (Gainesville: University Press of Florida, 2002), 38; Charles Hudson, The Southeastern Indians (Knoxville: University of Tennessee Press, 1976), 223-24, 366-67; Claudio Saunt, A New Order of Things: Property, Power, and the Transformation of the Creek Indians, 1733-1816 (Cambridge: Cambridge University Press, 1999), 11-12, 23-24.

7. This essay is inspired in part by Tiya Miles's ability to "read a history of place" into the Chief Vann House among the Cherokee during the nineteenth century. In addition to Tiya Miles, other scholars whose work have inspired this manuscript include Juliana Barr, Lisa Brooks, James Taylor Carson, David A. Chang, Kathleen DuVal, Robert Michael Morrissey, Jeffrey Ostler, Jon Parmenter, Joshua A. Piker, James P. Ronda, and Paul C. Rosier, all of whom similarly emphasize and explore the spatial configurations and definitions of Native America. Tiya Miles, The House on Diamond Hill: A Cherokee Plantation Story (Chapel Hill: University of North Carolina Press, 2011), 3; Juliana Barr, "Geographies of Power: Mapping Indian Borders in the 'Borderlands' of the Early Southwest," William E Mary Quarterly 68, no. 1 (2011): 5-46; Lisa Brooks, The Common Pot: The Recovery of Native Space in the Northeast (Minneapolis: University of Minnesota Press, 2008); James Taylor Carson, Making an Atlantic World: Circles, Paths, and Stories from the Colonial South (Knoxville: University of Tennessee Press, 2007); David A. Chang, "Borderlands in a World at Sea: Concow Indians, Native Hawaiians, and South Chinese in Indigenous, Global, and National Spaces," Journal of American History 98, no. 2 (2011): 384-403; Kathleen DuVal, The Native Ground: Indians and Colonists in the Heart of the Continent (Philadelphia: University of Pennsylvania Press, 2007); Robert 
the late seventeenth and early eighteenth centuries, but by the mid-1700s it was a thoroughly colonized space, inhabited and landscaped by Galphin, his family, tenants, employees, and the people he enslaved. Silver Bluff had also become by then one of the premier sites for Creek-British negotiation and a focus of activity for imperial authorities and agents. Yet the Creeks continued to use Silver Bluff as a distinctly Native place, despite its colonized or settled state, although its meanings and uses would change. ${ }^{8}$ The

Michael Morrissey, "The Power of the Ecotone: Bison, Slavery, and the Rise and Fall of the Grand Village of the Kaskaskia," Journal of American History 102, no. 3 (2015): 667-92; Jeffrey Ostler, The Lakotas and the Black Hills: The Struggle for Sacred Ground (New York: Viking Penguin, 2010); Jon Parmenter, The Edge of the Woods: Iroquoia, 1534-1701 (Lansing: Michigan State University Press, 2010); Joshua A. Piker, Okfuskee: A Creek Indian Town in Colonial America (Cambridge: Harvard University Press, 2006); James P. Ronda, “'We Have a Country': Race, Geography, and the Invention of Indian Territory," Journal of the Early Republic 19, no. 4 (1999): 739-55; Paul C. Rosier, “'They Are Ancestral Homelands': Race, Place, and Politics in Cold War Native America, 1945-1961," Journal of American History 92, no. 4 (2006): 1300-1326.

8. I define colonized space as a place thoroughly settled and populated, or landscaped and terraformed, by Europeans. In this case, Silver Bluff-formerly the site of Creek and Yuchi settlements-had become a distinct southern plantation by the mid eighteenth century, divested of its original inhabitants and resources. In defining colonialism in this context, I draw extensively on the theories of "settler colonialism," or the process by which European immigrants and settlers exerted several pressures on Native populations, who were forced to relocate from said lands. Factors include the obvious, such as encroachments or invasion of indigenous territories, and more covert processes, such as cultivating financial debts (which could then be turned into treaties of dispossession), terraforming the land by means of cattle and livestock, and so on. Works by Bethel Saler, Roxanne Dunbar-Ortiz, Jodi Byrd, Patrick Wolfe, Frederick E. Hoxie, Lorenzo Veracini, Walter L. Hixon, and Lisa Ford have proven critical to my ideas about the type of colonialism the Creek Indians sought to counter at Silver Bluff in the mid to late eighteenth century. Bethel Saler, The Settlers' Empire: Colonialism and State Formation in America's Old Northwest (Philadelphia: University of Pennsylvania Press, 2014); Roxanne DunbarOrtiz, An Indigenous Peoples' History of the United States (Boston: Beacon Press, 2014); Jodi Byrd, The Transit of Empire: Indigenous Critiques of Colonialism (Minneapolis: University of Minnesota Press, 2011); Patrick Wolfe, "Settler Colonialism and the Elimination of the Native," Journal of Genocidal Research 8, no. 4 (2006): 387-409; Frederick E. Hoxie, "Retrieving the Red Continent: Settler Colonialism and the History of American Indians in the United States," Ethnic and Racial Studies 31, no. 6 (2008): 1153-67; Lorenzo Veracini, "Introducing Settler Colonial Studies," Settler Colonial Studies 1, no. 1 (2011): 1-12; Walter L. Hixon, American Settler Colonialism: A History (New York: Palgrave Macmillan, 2013); Lisa Ford, 
familial, political, economic, and cultural meanings with which the Creeks imbued Silver Bluff made Galphin's plantation as much a Creek space as a colonial one. Silver Bluff thus remained within the Creeks' physical and cosmological worlds, in spite of its transformation under colonial occupation.

Indigenous processes of spatial reintegration, such as those at Silver Bluff, occurred time and again in the Native South during the eighteenth century. Creek headmen often envisioned major colonial cities as connected to their towns and people by a "white path from thence [Charleston] to Savannah," whereby, they avowed, "the Children on both sides will hang together in friendship." Emistisiguo, an Upper Creek mico, thought that "no small breach between them should Spoil the Old white Path, which comes from Charlestown to the [Creek Nation]," and that the "Path was always to be free for Both Parties to Pass and Repass upon." Creek leaders, therefore, not only crafted their own meanings of colonial cities but also redefined what those places meant to Creek people, just as they did with Silver Bluff. ${ }^{9}$

The plantation home of John Stuart, an Indian trader to the Cherokees and later the British superintendent for Indian Affairs in the South, presents an even more specific parallel to Silver Bluff. Before relocating to Charleston in 1772, Stuart had lived in nearby Cherokee Country. Cherokee headmen, led by Attakullakulla (the Little Carpenter), considered Stuart's grounds a Cherokee space, and they invested it with their own cultural and religious meanings; there they conducted politics and trade or conversed as friends and kinsmen, in much the same way as the Creeks did at Silver Bluff. But records for the Silver Bluff site reveal more of its nuances and the intersections of kinship, politics, economics, and culture, while showing how the Creeks used such multifaceted understandings to reincorporate that space back into their world. Such insights, in turn, permit a richer consideration of how Native peoples in the South, and indigenous societies elsewhere in North America, invested colonized spaces with specific, complex, and multilayered meanings.

Settler Sovereignty: Jurisdiction and Indigenous People in American and Australia, 1788-1836 (Cambridge: Harvard University Press, 2011).

9. "A Treaty of Peace and Commerce Held at the Old Town," November 6, 1777, George Galphin Letters, 1777-1779; Upper Creek Headmen to John Stuart, May 1, 1771, in John T. Juricek, ed., Early American Indian Documents, vol. 12, Georgia and Florida Treaties, 1763-1776 (Frederick, Md.: University Publications of America, 1989-), 97. 
The Creek Indians, then, pushed back against the colonization of the American South in ways that scholars have not yet fully understood or articulated. By integrating Silver Bluff-a former Native space - back into their physical and spiritual worlds, the Creeks converted what Europeans believed to be a colonized ground into a Native space, which European observers-even Galphin himself-failed to comprehend. Using Silver Bluff as our litmus test, we can imagine that this indigenous process of spatial reintegration occurred time and again throughout North America as Native Americans interacted with Euro-Americans over centuries. With such understanding, we can complicate the American narrative by demonstrating how indigenous peoples navigated and challenged colonization in ways that were tied to specific places or spaces in colonized America.

Creek people understood their world in personal and spatial dimensions, and they attached very intimate meanings and connections to the land. This was nowhere more evident than in the emphasis Creek people placed on their towns and communities, or talwas, around which all manners of life occurred. As scholars of Native America have demonstrated in their work, Creek society was first and foremost a "world of towns." From the annual Busk festival, town councils, and the preparations for war to communal dances, ball games, ritual gatherings, and economic exchanges, Creek life unfolded primarily in the town center. "The Towns," British officials observed, "may be considered as so many Different Republicks which form one State, but each of these Towns has separate Views and Interests." The Creeks shared a great reverence for certain spaces, then, which they imbued with their own meanings and uses. ${ }^{10}$

The Creek Indians also privileged their relationships with family and community. In Creek society, personal and spatial worldviews existed side by side and conditioned how Creek people perceived the world around them and structured their relationships with outsiders. On the one hand, the Creeks and other indigenous peoples assimilated Europeansparticularly traders like Galphin-into their societies, often through ritual

10. Joshua Piker, “'White \& Clean' \& Contested: Creek Towns and Trading Paths in the Aftermath of the Seven Years' War," Ethnohistory 50, no. 2 (2003): 332 ("world of towns"); Steven C. Hahn, The Invention of the Creek Nation, 1670-1763 (Lincoln: University of Nebraska Press, 2004), 20 (Creeks' town-centrality); Clarence Edwin Carter, ed., "Observations of John Stuart and Governor James Grant of East Florida on the Proposed Plan of 1764 for the Future Management of Indian Affairs," American Historical Review 20, no. 4 (1915): 828 ("Republicks"). 
adoption or marriage to an indigenous woman. By doing so, they invited Europeans into a personal relationship, although Europeans were forced to conform to indigenous expectations of reciprocity and mutual exchange. ${ }^{11}$ This is why colonial administrators and their agents addressed Creek micos as their "friends" and "brothers," invoking the kinship ties between Native women and European traders. On the other hand, Creek and European leaders articulated a vernacular of white paths and white grounds, or spaces that embodied the relationships between individuals, as well as the alliance between the Creek Confederacy and British Empire. This combination of the personal and spatial was all the more visible in times of violence between Creek and British people, such as in April 1774, when Emistisiguo of Little Tallassee met with Georgia's Governor James Wright and appealed to him as one of his "Friends and Brothers." Emistisiguo then invoked the "white path to Charleston," the trade path that connected Creek towns to the British colonies, and promised to do all in his power to "hold the white people fast by the hand." Emistisiguo in this instance revealed the intensely spatial and personal dimensions of the Creek world. ${ }^{12}$

The spatial and personal also intersected at George Galphin's Silver Bluff plantation. Before Galphin settled at Silver Bluff in the 1750s (figure 1), the area was the site of a "Settlement of Euchee Indians[.] On both Sides of the River are Fields of Corn planted by them." ${ }^{13}$ The Yuchi community was an offshoot of the larger Yuchi town in Creek Country, situated near the Lower Creek towns of Cusseta and Coweta. While at Silver Bluff, the Yuchis carved out the "Yuchi trail that led straight across middle Georgia to Coweta" and established the easternmost reaches of the Creek Confederacy. The incessant demands for land by European settlers, however, and continual attacks by the Cherokees during the Creek-Cherokee Wars,

11. Andrew Frank has demonstrated in his work on Creek customs of "incorporating ethnic outsiders" that "intermarried individuals and their families bridged the gap between southern and Creek societies with their kinship networks, cultural practices, political power, and economic functions," serving "the needs of both communities." Andrew K. Frank, Creeks and Southerners: Biculturalism on the Early American Frontier (Lincoln: University of Nebraska Press, 2005), 4, 16.

12. "Conference between Governor Sir James Wright and the Upper Creek Indians," April 14, 1774, in K. G. Davies, ed., Documents of the American Revolution, vol. 8, Transcripts, 1774 (Shannon: Irish University Press, 1972-), 90-95 ("Friends and Brothers," "white path to Charleston," "hold the white people fast").

13. Henry Mouzon, An Accurate Map of North and South Carolina with Their Indian Frontiers, HMap1775s6, Hargrett Rare Book \& Manuscript Library, University of Georgia, Athens. 


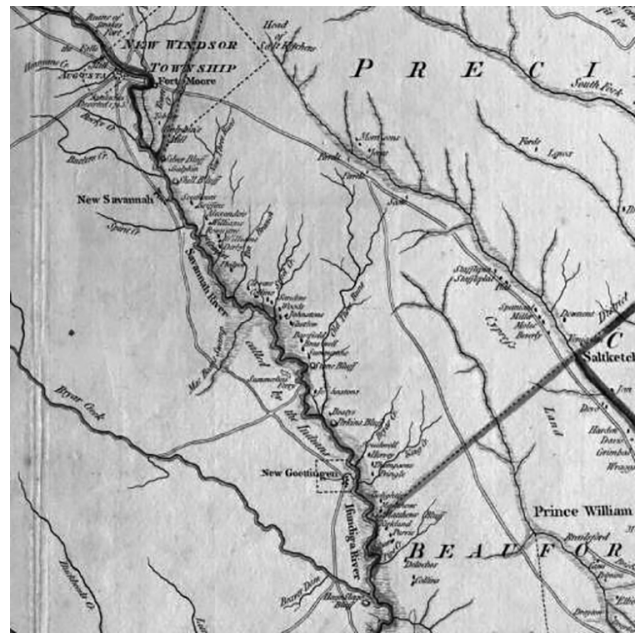

Figure 1. Map showing Silver Bluff (located slightly south of New Windsor Township, along the Savannah River). From Henry Mouzon, An Accurate Map of North and South Carolina with Their Indian Frontiers, 1775. Hargrett Rare Book \& Manuscript Library, University of Georgia.

threatened the Yuchi presence at Silver Bluff. James Oglethorpe remarked as early as 1736 that the Yuchis were "vext" with "the Carolina people [who] swam a great Herd of Cattle ... and sent up Negroes and began a Plantation ... not far from the Uchees Town." It did not help matters that Georgia residents, such as the minister Johann Martin Bolzius, believed the "Uchy ... are the worst of all ... [having] disturbed and robbed us." Bolzius demanded that the colonial government grant his community of Salzburger immigrants "that Land . . . which is said, belongs to the Uchys." By the mid-1740s, the Yuchi had left Silver Bluff and returned to their town within Creek Country. ${ }^{14}$

14. Meeting of the Presidents and Assistants in Council, September 25, 1750, in Colonial Records of the State of Georgia, vol. 6, Proceedings of the President and Assistants from October 12, 1741 to October 30, 1754, ed. Allen D. Candler (Atlanta: Franklin Printing and Publishing, 1906), 331; Journal of William Stephens, 17371740, in Colonial Records of the State of Georgia, vol. 4, Stephens' Journal, 1737-1740, ed. Allen D. Candler (Atlanta: Franklin Printing and Publishing, 1906), 666 ("Euchee"); John McKay Sheftall, "Ogeechee Old Town: A Georgia Plantation, 1540-1860," Richmond County History Journal 14, no. 2 (1982): 29 ("Yuchi trail"); entry for April 2, 1741, in Colonial Records of the State of Georgia, vol. 5, Journal of the Earl of Egmont, from June 14, 1738 to May 25, 1744, ed. Allen D. Candler (Atlanta: Franklin Printing and Publishing, 1906), 485 (Creek-Cherokee War); 


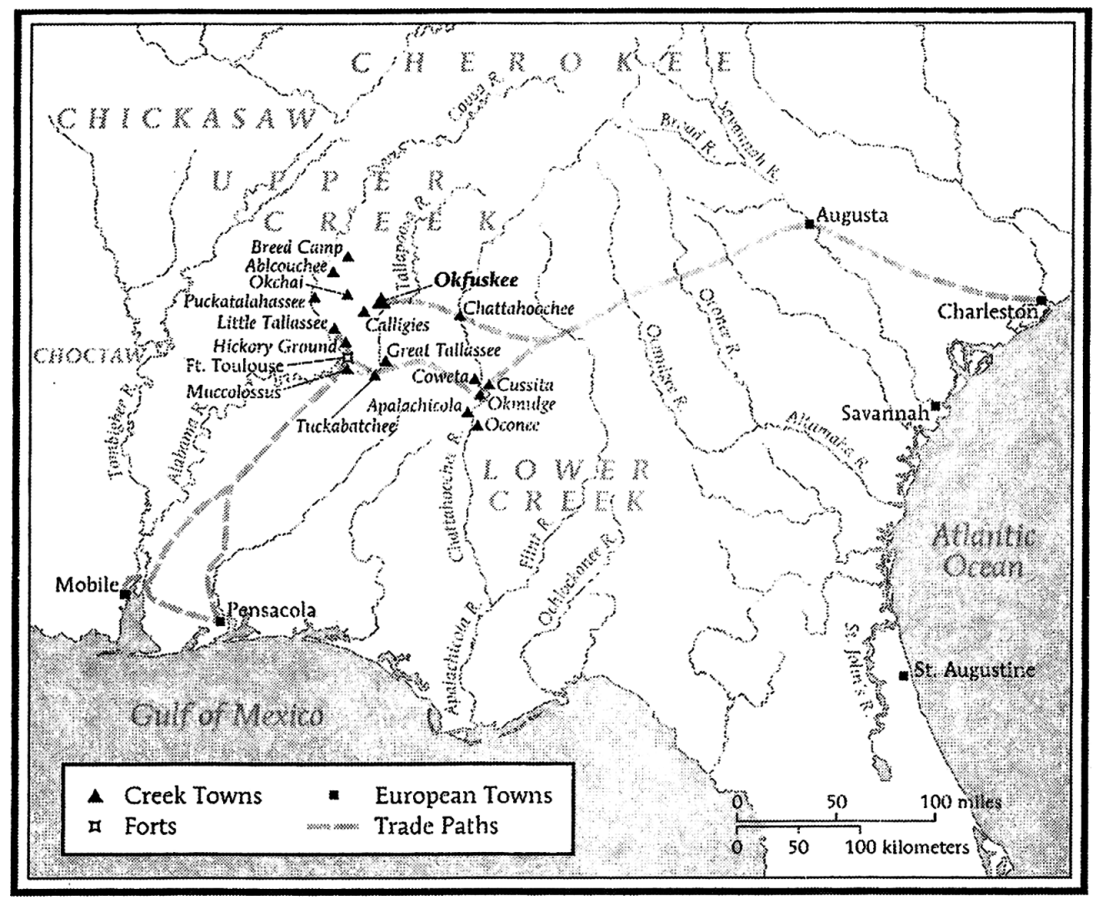

Figure 2. Map of Creek Country and Creek Path (Creek Path is the dashed line, and Silver Bluff is located just outside Augusta, along the Creek Path). From Joshua Piker, Okfuskee: A Creek Indian Town in Colonial America (Cambridge: Harvard University Press, 2004).

It was George Galphin, though, rather than the Salzburgers, who ultimately occupied Silver Bluff, which was strategically located only a few miles south of Augusta, atop the bluffs overlooking the Savannah River. The property was situated at the crossroads where the "Creek Path" bisected Britain's southern colonies, on the border that separated South Carolina and Georgia (figure 2). ${ }^{15}$ Galphin accumulated 7,247 acres at Silver Bluff

James Oglethorpe to the Georgia Trustees, May 18, 1736, in Colonial Records of the State of Georgia, vol. 21, Original Papers, Correspondence, Trustees, General Oglehtorpe and Others, 1735-1737, ed. Allen D. Candler (Atlanta: Charles P. Byrd, 1910), 161 ("vext," "great Herd," "Plantation"); Johann Martin Bolzius to Mr. Verelst, February 24, 1745/46, in Colonial Records of the State of Georgia, vol. 25, Original Papers, Correspondence, Trustees, General Oglethorpe and Others, 1745-1750, ed. Allen D. Candler (Atlanta: Charles P. Byrd, 1910), 10 (“worst of all," "Uchys").

15. Piker, Okfuskee. 
over the course of two decades, and he divided those lands into two separate areas; he reserved the northern lands as his family's residence and devoted them to plantation agriculture, while employing the southern lands for the deerskin trade. The Silver Bluff landscape also contained Galphin's luxurious brick houses, an array of outbuildings that included kitchens, storehouses, water wells, warehouses and barns that stored crops, machinery, and animals, sawmills and gristmills that powered his businesses, trade stores and taverns where travelers and traders congregated, a private wharf where sloops and other ships docked, a cowpen that was home to " 3 or $4000 \ldots$ stocks of cattle," and even a "Baptist Church" where Galphin's enslaved people gathered on "Saturday evening[s]." There were, in addition, miles of symmetrically planted corn, rice, and indigo. Galphin methodically transformed Silver Bluff from a Native landscape into a colonized space. ${ }^{16}$

Yet the Creek Indians did not abandon Silver Bluff; they instead continued to use the space in their own ways, reshaping it into a white ground, and reintegrating it into the Creek world. First, the Creeks reinvented Silver Bluff as a familial space. Before Galphin took possession of Silver Bluff in the 1750s, he had been the resident trader to Coweta, one of the leading towns among the Lower Creeks. During this time, Coweta's micos matched Galphin with Metawney, a "woman of . . f family distinction" and the daughter of Chigelli, one of Coweta's micos and the "Tustenogy Mico," or "Great Warrior." ${ }^{17}$ Because of the matrilineal structures of Creek society,

16. Tammy Forehand et al., "Bridging the Gap between Archaeologists and the Public: Excavations at Silver Bluff Plantation, the George Galphin Site," Early Georgia 32, no. 1 (2004): 56-64; Thomas Brown to Patrick Tonyn, June 10, 1776, Board of Trade and Secretaries of State: America and West Indies, Original Correspondence, Board of Trade: East Florida, 1763-1777, Colonial Office Records series 556, British National Archives, Kew, 667 (“3 or 4000”); An Account of Life of David George, Canada's Digital Collection, www.blackloyalist.com/cdc/documents/diaries/george_a_life.htm ("Church," "Saturday").

17. My attempts to learn the identity of Metawney's father, the elusive Coweta “Tustenogy Mico," otherwise known as the War King or Great Warrior of Coweta, took a great deal of work. In tracking references to this unnamed individual, I found Chigelli proclaimed himself as the Coweta "Tuskeestonnecah Mico War King" in December 1746, before stepping down from that position in 1747 in favor of Sempoyaffee. Malatchi confirmed Chigelli's title when describing Chigelli as "a great Warriour \& Commanded the Nation . . . till last Busk [1747].” When Galphin entered Coweta between 1738 and 1741, the "War King" of Coweta was probably Chigelli. John T. Juricek, Colonial Georgia and the Creeks: Anglo-Indian Diplomacy on the Southern Frontier, 1733-1763 (Gainesville: University of Florida Press, 2010), 54; "Chigelli's Talk to Horton," December 4, 1746, in John T. Juricek, ed., Early American Indian Documents, vol. 11, Georgia Treaties, 1733-1763 (Frederick, Md.: 
women like Metawney were the main source of political authority, spiritual power, cultural knowledge, and lineage within Creek communities, and the principal vehicles through which Creeks incorporated outsiders into their world. Metawney enfolded Galphin into her family and matriline, a kin circle that included some of the Creek Confederacy's leading micos, such as the " 4 vile Brothers" and the "owners of the Town Ground": Escotchaby, Sempoyaffee, the Second Man of Coweta, and Ufylegey. ${ }^{18}$ Galphin's union with Metawney enabled his transition from cultural outsider to cultural insider - as an in-law — and prompted other micos like the Tallassee King and Captain Aleck to consider Galphin a "Creek man." Galphin's pairing with Metawney had, for all intents and purposes, transformed him into a Creek townsman, and thereafter the Lower and Upper Creeks "looked upon [him] as an Indian." ${ }^{19}$

When Galphin retired from Coweta to Silver Bluff in the early 1750s, Metawney joined him there, and the members of her family and matriline who frequented their plantation reshaped Silver Bluff as a distinctly familial space. Indeed, Creeks may have even been responsible for encouraging Galphin to relocate to Silver Bluff from Coweta. At Silver Bluff, Metawney would probably have insisted on a Creek upbringing for their children: George, John, and Judith. Within Creek matrilineal society, maternal uncles managed the children's education, so the responsibility would have fallen to Metawney's brothers: Escotchaby, Sempoyaffee, Ufylegey, and the Second Man. This perhaps explains why British agents repeatedly observed "Scochaby ... \& Simpoyahfy stay some time," anywhere from "four Days"

University Publications of America, 1989-), 132; "Malatchi's Speech to Heron," December 7, 1747, in Juricek, Early American Indian Documents, 11:148-52.

18. Charles Hudson, The Southeastern Indians (Knoxville: University of Tennessee Press, 1976), 185-88, 190.

19. "Bonds, Bills of Sale, \& Deeds of Trust," October 27, 1809, Le Conte Genealogical Collection, MS 71, Book D, Hargrett Rare Book \& Manuscript Library, University of Georgia, Athens, 270-72 ("distinction"); Thomas Nairne, Nairne's Muskohogean Journals: The 1708 Expedition to the Mississippi River, ed. Alexander Moore (Jackson: University Press of Mississippi, 1988) (Creek matrilineal structures); Edmond Atkins to Governor Henry Ellis, January 25, 1760, Selected Eighteenth Century Manuscripts, Collections of the Georgia Historical Society, vol. 20, ed. Albert Sidney Britt Jr. and Anthony Roane Dees (Savannah: Georgia Historical Society, 1980), 136-43 ("vile Brothers," “owners"); Frank, Creeks and Southerners, 11 (inclusivity), 18 (outsider), 35 (“Creek man”); Tallassee King's Talk delivered to Governor \& Council, September 22, 1784, Creek Indian Letters, Talks \& Treaties, 1705-1837, WPA Georgia Writers' Project, MS 1500, Hargrett Rare Book \& Manuscript Library, University of Georgia, Athens, 161-63 (“as an Indian”). 
to " 15 days at [Galphin's] Home." Such frequent contact cultivated a profound sense of family and community at Silver Bluff, as George Galphin Jr. affirmed when he, later in life, acknowledged, "My brother [and I] have a good deal of influence in the Cowetas, through our connexion there." Creek micos from other towns-such as Tallassee, Okfuskee, Cusseta, Chehaw, and Yuchi-also frequented Silver Bluff to see their "brother" and "friend" Galphin. He, in turn, was continually billeting and entertaining his Creek guests, who preferred to stay or "wait . . . at Mr. Golphin's" rather than in nearby Augusta, Savannah, or Charleston. ${ }^{20}$ Ironically, European observers missed this familial connection, remarking instead on Galphin's "kindness and hospitality toward the Indians, always receiving them with good humor and furnishing them amply with such necessaries as they stood in need of at his hospitable dwelling." Silver Bluff, then, was a Creek space more than a colonized ground. ${ }^{21}$

Familial connections allowed Creek micos to appoint Silver Bluff as a white ground, a place where Creek people could safely and comfortably meet with Europeans to negotiate treaties, present grievances, exchange deerskins, or simply talk. By drawing on Galphin's standing as a Creek man, the Creeks transformed Silver Bluff into not only a kin space, but also a political space endowed with indigenous meanings. The intimate relationship between Galphin and Metawney served more than one purpose, then, since Native leaders throughout the South viewed go-betweens like Galphin

20. As Paul Kelton recently demonstrated, indigenous peoples often preferred to avoid crowded colonial centers like Savannah and Charleston owing to the potential for contracting diseases that they might communicate to the rest of their community. Paul Kelton, Cherokee Medicine, Colonial Germs: An Indigenous Nation's Fight against Smallpox, 1518-1824 (Norman: University of Oklahoma Press, 2015).

21. Hudson, The Southeastern Indians, 187; Edmond Atkin to William Henry Lyttelton, March 7, 1760, William Henry Lyttleton Papers, 1756-1760, box 15: March 1760-April 1762, William L. Clements Library, University of Michigan, Ann Arbor ("Simpoyahfy"); George Galphin to John Stuart, June 2, 1768, in Juricek, Early American Indian Documents, 12:46-47 ("15 days"), 210-11 ("Brothers," "Friends"); George Galphin to James Grant, March 26, 1770, James Grant of Ballindalloch Papers, 1740-1819, microfilm 687, reel 19, David Library of the American Revolution, Washington Crossing, Pa. ("four Days," "My House"); George Galphin to the Commissioners for Indian Affairs in the Southern Department at Augusta, May 27, 1789, in U.S. Congress, American State Papers: Indian Affairs (Buffalo: W. S. Hein, 1998), 35-36 ("My brother," "influence"); Pennsylvania Gazette, 1728-1800, July 3, 1760, South Caroliniana Library ("wait"); "Bonds, Bills of Sale \& Deeds of Gift," October 27, 1809, Le Conte Genealogical Collection, 270-72 ("hospitable dwelling"). 
as proxies in the negotiations with Europeans. The Creeks thereby used their relationship with Galphin as a link to British authorities in North America. When Lower Creek micos met with imperial agents after a series of violent incidents in late 1771, the headmen expressed their "hope that the path will be white to Charlestown, and likewise the same from here [Chehaw] to you at Savannah, and the same path to be white to Mr. Galphin's." It is no coincidence that Creek micos invoked the white path to Silver Bluff as well as to Charleston and Savannah. Imperial officials quickly grasped the necessity of "invit[ing] the principal Chiefs and Head Warriors of the Creek Nation, to meet at Silver Bluff . . . to renew and Strengthen the ancient Compacts and Covenant Chains made between His Majesty and said Tribes." Creek people perceived Silver Bluff as their bridge to the east as they negotiated and navigated empire in the South. ${ }^{22}$

The intersection of the familial and political at Silver Bluff appeared in other ways. Creek micos, for example, went to Galphin's plantation to meet imperial authorities from the colonies. In 1761 Lower Creek headmen employed "Mr. Galphin's Talk" to relay "the bad News of [three Creek Indians] having killed one White Man near Augusta." The micos described to the governors of South Carolina and Georgia how the culprits tried to escape to Cherokee Country and were stopped by Coweta's leaders, who "persuaded them to come home" and then went to "acquaint the Indians [already] at Mr. Galphin's" of the incident. The Creek leaders then left Silver Bluff accompanied by Galphin and made their way "to Charles Town" to resolve the conflict. In other instances, Creek headmen asked Galphin to "write down and Acquaint both Governours and the beloved Man of it," or to relay their "Talk" to Savannah and Charleston. In one case, Galphin penned a letter to imperial agents "to give Reasons why he thought the Murders were not done by the lower Creeks." In 1768, when English and Irish settlers "plundered and burnt" a Creek town, the Creek victims journeyed to Silver Bluff and reported to the micos they were "now at Mr. Galphin's ... [and] desire that there may be no false News, or disturbances amongst you \& the White People," despite the fact that their "Houses are burnt $\&$ goods carried away." These and other instances show

22. Lower Creek Chiefs to James Habersham, March 17, 1772, in Juricek, Early American Indian Documents, 12:111 ("path will be white"), emphasis in original; "Journal of the Superintendent's Proceedings," September 1768, Records of the Colonial Office, America and West Indies: Indian Affairs, ser. 1, reel 4, vol. 70, British Public Records Office (microfilm), University of Oklahoma, Norman ("invite," "Compacts"). 
how the Creeks employed Silver Bluff to negotiate the violence of empire in the South. ${ }^{23}$

Silver Bluff, then, was a preferred meeting place for Creek people because it was white ground. Thus, on the eves of the Creek-British congresses in 1763 and 1773, and when running out the treaty boundary lines in 1765 and 1768, Lower and Upper Creek micos spent their days and nights at Silver Bluff. British officials therefore had to go to Silver Bluff before proceeding to more formal venues at Augusta, Savannah, or Charleston. As Escotchaby of Coweta told Superintendent Stuart, even though "you have sent for me [and] I will wait upon you ... I, and all the rest of the Head Men, propose being at Mr. Galphin's.” At Silver Bluff, Creek and British leaders met face to face for encounters ranging from informal "Conversation[s] . . . at Mr. Golphin's" before or after treaty negotiations to official convocations. "Mr. Galphin's" was ultimately where Creek leaders opened a "channel" and "conversed" with the British Empire. And it was there that the Tallassee King informed British agents that "Mr. Galphin ... Loves his Children and the Lands he [the Tallassee King] lives on." The Tallassee King added that "he always received good Talks from this place [Silver Bluff]." Such statements reflect how the Creeks reinvented Silver Bluff as a Native space, particularly as a white ground-a place of indigenous mediation with the British Empire-and how they reincorporated that space into their world. ${ }^{24}$

23. "A Talk from the Cowetas," June 22, 1761, in Colonial Records of the State of Georgia, vol. 8, Proceedings and Minutes of the Governor and Council, March 8, 1759 to December 31, 1762 Inclusive, ed. Allen D. Candler (Atlanta: Franklin Printing and Publishing, 1907), 553-57 ("bad News," "persuaded," "Mr. Galphin's," "Charles Town"); George Galphin to the Governor, Council, \& Georgia Assembly, January 1764, in Candler, Colonial Records of the State of Georgia, 9:114-16 ("beloved Men," "Reasons"); "A Talk from Howmatcha to Escotchaby," August 27, 1767, Thomas Gage Papers, 1754-1807, American Series, vol. 69 ("Mr. Galphin's," "plundered," "false News," "Houses").

24. Lower Creek Headmen to John Stuart, October 1, 1768, in Juricek, Early American Indian Documents, 12:63 ("rest of the Head Men"); "Talks at a Meeting between Traders and Headmen of the Creek Indians at Little Tallassie," April 8, 1764, in Colonial Records of the State of Georgia, vol. 28, pt. 2, Original Papers of Governor Wright, President Habersham, E Others, 1764-1782 (Athens: University of Georgia Press, 1979), 39-43 ("Conversation”); John Stuart to the Governors, October 20, 1763, Colonial Records of the State of Georgia, vol. 39, Georgia Trustees' Letter Book, 1732-1738 (microfilm), Georgia Historical Society, Savannah, 329 ("channel," "converse"); Tallassee King to George Galphin, November 3, 1779, George Galphin Letters, 1778-1780, Ayer MS 313, Newberry Library, Chicago ("Loves," "always received"). 
British authorities, however, entertained very different ideas about the political importance of Silver Bluff. For men of empire like Governor Wright and Superintendent Stuart, Silver Bluff represented an "imaginary wall" segregating the Creek Confederacy from the colonies; it provided "the only protection [the empire] had left" in the South. Whereas the Creeks perceived Silver Bluff as a white ground connected to Creek Country along a white path, imperial officials regarded the site as a last stop in North America before entering the uncivilized "wilderness" of the Native South. Instead of crossing a threshold into Native domains, British administrators embraced Silver Bluff as an imperial space and a more "civilized" locale in which to host negotiations. Imperial agents thus acceded to demands from Creek micos to "meet at Silver Bluff . . . to renew and Strengthen the ancient Compacts" between them. While there, the governors and superintendent made sure that the Creek dignitaries should want "for nothing of the Provision Kind or Liquor and some trifling Things." To these men of empire, Silver Bluff was a place where they could placate Creek leaders and persuade them to sign treaties or give "satisfaction" in times of violence. During treaty negotiations in 1763, for example, British agents reportedly asked Galphin to host private talks about a potential cession of land. Silver Bluff became a repository for the Treaty of Augusta (1763) itself, after the interim governor of Georgia, James Habersham, misplaced the original document. "I cannot find the Treaty entered into with the Indians . . . in the year 1763," he wrote, "and am at a great Loss for it." He then asked Galphin "if you have it, I shall be greatly obliged to you for it," and it arrived soon after from Silver Bluff. ${ }^{25}$

Silver Bluff was also a destination point and conduit for the intelligence and rumors that flooded the South during the mid- to late eighteenth century. As scholars have demonstrated, "rumor had power." It "shaped and reflected perceptions on the colonial ... frontiers," and could turn friend into foe. In times of conflict, or when rumors of violence circulated, Creek

25. Edward Cashin, Lachlan McGillivray, Indian Trader: The Shaping of the Southern Colonial Frontier (Athens: University of Georgia Press, 1992), 251 ("wall," "protection”); Pennsylvania Gazette, 1728-1800, July 5, 1775, South Caroliniana Library ("wilderness"); “Journal of the Superintendent's Proceedings," September 1768, Records of the Colonial Office, America and West Indies: Indian Affairs, ser. 1, reel 4, vol. 70, 76 ("Compacts"); George Galphin to John Stuart, June 2, 1768, Thomas Gage Papers, 1754-1807, American Series, vol. 78 ("Provision,” "Orders," "private talks"); James Habersham to George Galphin, December 12, 1771, Habersham Family Papers, 1712-1842, folder 4, MS 1787, Georgia Historical Society, Savannah ("Loss," “obliged"). 
micos used intelligence from Silver Bluff to sift through the lies, half-truths, and misinformation. In summer 1759, for example, reports alleged that several "Murder[s] [had] been committed by the Creeks" and "it is feared [they] will soon do more." On hearing the news, Creek townsmen went to Silver Bluff and told Galphin "about 200 Yards off the Creek Path, [they had] observed some Pack-Saddles lying about the Buzzards flying." But they claimed the violence had been perpetrated by the Cherokees. And when rumors flooded the colonies soon after that "it is generally believed, whether Thomson [the slain trader] was killed and his Goods taken by Creeks or Cherokees, that the Upper Creeks had some Hand in it," Galphin quickly intervened. He "sent up . . . a Messenger" from Silver Bluff with "Accounts of the Affair" in which he and Creek micos had "obtain[ed] Satisfaction from the Cherokees" that brought rumors and fears to a rest. Later, unsubstantiated "a Count[s] from the Creeks" told of "Six Savvannaws Come in there \& is about making a peace between the Creeks \& Choaktaws and it is thought they want all the Indians to Joyne against the white people." Lower Creek micos headed immediately to Silver Bluff to deal with the matter. Superintendent Stuart subsequently reported the rumors as false, having received "Creek talks . . . forwarded by Mr. Galphin." Time and again, the Creeks relied on Silver Bluff to combat the "several evil minded people [who] have been industrious to spread about ... false Report[s]" in the South, particularly rumors "that the Indians were disgusted" and intended to do violence. ${ }^{26}$

The importance of Silver Bluff as a mediating space also extended to the boundary lines that divided the Creek Confederacy and the British colonies. After the Seven Years' War, one of the most frequent complaints by Creek micos involved the "Red \& White peoples' not knowing the Line, [that] causes disturbance." It was crucial for Creek and British leaders to delineate

26. Gregory Evans Dowd, Groundless: Rumors, Legends, E Hoaxes on the Early American Frontier (Baltimore: Johns Hopkins University Press, 2015), 1 ("power"), 2 ("perceptions"); London Evening Post, June 6-8, 1761, 17th and 18th Century Burney Collection Database, British Library, London ("Silver Bluff," "Oakfuskee," "Buzzards," "killed," "feared," “Thomson," "Hand," "Affair," "Satisfaction”); George Galphin to James Grant, March 26, 1770, James Grant of Ballindalloch Papers, 1740-1819, reel 19 ("Last a Count," "Joyne"); John Stuart to Thomas Gage, August 27, 1767, Thomas Gage Papers, 1754-1807, American Series, vol. 69 ("forwarded"); "Certificate upon Oath of Four Indian Traders," November 20, 1756, in Colonial Records of the State of Georgia, vol. 28, pt. 1, Original Papers of Governor Reynolds, Ellis, Wright, and Others, 1757-1763, ed. Allen D. Candler (Athens: University of Georgia Press, 1976), 79 (“evil minded," “disgusted”). 
the boundaries between their peoples, which required congresses in 1763, 1765, and 1768. But when Creek headmen like Escotchaby, the Blue Salt King, and Sallichie promised Superintendent Stuart they would "come and Run the line," they would do so only when they "come to Mr. Galphin's in the Spring," and they told Stuart to "send somebody to Mr. Galphin's ... to meet [us] there." Ironically, the new borders that Creek and British leaders negotiated ran along the trade paths between Lower Creek towns and Silver Bluff and passed through Creek hunting grounds at some distance from the lower towns. Creek micos even inserted Silver Bluff into the boundary lines: the border established by the Treaty of Augusta (1763) ran "from the rock, down to the Savannah River, and the other way, from the said rock to Mr. Galphin's cowpen." As Sempoyaffee, Captain Aleck, and other Creek headmen concluded, this new line was intended "to prevent any future disturbance." Here Creek micos not only dictated where the borders were fixed, but had put their faith for the future in a site where politics met kinship, a place that straddled the thin line that separated Creek and British people. ${ }^{27}$

The Creek Indians also employed Galphin's plantation as a space of economic exchange. As a "Creek man" and in-law, Galphin was beholden to Creek rituals of reciprocity. The Creeks thereby treated Silver Bluff as they did their own towns, assuming its doors and coffers were always open. European observers noted that the Creeks were "always ... furnishe[d] . . . amply with necessaries as they stood in need of at his hospitable dwelling at Silver Bluff." Creek hunters, accompanied by their "Wives \& Children," maintained a constant presence at Silver Bluff, their stays varying anywhere from "four days" to several weeks. In one memorable instance in early 1778, a group of Creeks tested Galphin's patience by making camp for a staggering "9 weeks," during which Galphin complained "I was not one Day Clear of [those] Indians all the time I was there." To Creek peoples, Silver Bluff provided them with one of many economic strategies to support their communities, as a place where they attained necessaries, presents, and other goods gratis or on credit. The number of Creeks who used Silver Bluff in such ways prompted British traders to complain that Galphin "carr[ied] on the advantageous [and unfair] Trade with them." Imperial administrators, however, recognized the frequency with which the Creeks flocked to Silver

27. Lower Creek Headmen to John Stuart, September 19, 1767, Records of the British Public Records Office, Colonial Office, ser. 5, pt. 1, reel 5, vol. 69 ("Red \& White," "run the line," "come to Mr. Galphin's," "spring"); Congress at Augusta, October 23, 1763, in Candler, Colonial Records of the State of Georgia, 39:331 ("Mr. Galphin's cowpen"; emphasis in original), 360-61 ("future disturbances"). 
Bluff, and they designated it as one of the repositories for the "distribution of presents to the Indians," which further added to its economic significance. $^{28}$

More important, the Creeks considered Silver Bluff one of their main sites for the deerskin trade. At Galphin's plantation, Creek hunters and their families traversed the Creek Path trade route connecting Creek communities to the colonies, which ran through Silver Bluff (see figure 2), or one of several other trade paths branching off the Creek Path, such as Godolphin's Path, which led straight to Silver Bluff. Once the Creeks arrived, they exchanged the furs of white-tailed deer-harvested in the winter months-for the necessaries, firearms, and various commodities stored at Silver Bluff. Reciprocally, it was along this landscape of paths that Galphin's traders, such as the "White Boy," a Creek factor from the town of Pucknawheatly (Standing Peach Tree), and the "Half-Breed Abraham of Coweta," made their way to Creek Country. Abraham, in one instance, brought into Silver Bluff "1186 lbs. Raw Skins . . 82 dressed skins . . . [some] lightly damaged skins ... . [and] $40 \mathrm{lb}$. Beaver [skins]" and then returned to Coweta with coffee, soap, nails, vermillion, bullets and gunpowder, blankets, sugar, salt, rum, trading shirts, and other goods. Meanwhile, the White Boy trafficked in as much as "1936 weight [lbs.] deerskins in the hair" (i.e., raw) on a weekly basis. Silver Bluff proved so important to Creek economies that when the set prices for skins fluctuated wildly, as they did in 1767, Creek micos demanded British administrators and Indian traders meet at Silver Bluff. Here Creek headmen, British authorities, and the traders passed new regulations and a tariff, "read [aloud] by Mr. George Galphin and agreed to by the Indians without any Objection."

The Creeks also used Silver Bluff as an access point to the trans-Atlantic world of goods, exchanging deerskins for commodities from Asia, Africa, Europe, and other parts of North America. What remains of the Silver

28. "Bonds, Bills of Sale \& Deeds of Gift," October 27, 1809, Le Conte Genealogical Collection ("necessaries"); George Galphin to John Stuart, January 6, 1764, Records of the Colonial Office: Original Correspondence, Plantations General, 1689-1952, Colonial Office Record series 323/18, document 178 ("wives and children"); George Galphin to Henry Laurens, June 25, 1778, The Papers of Henry Laurens, vol. 13, March 15-July 6, 1778, ed. David R. Chesnutt and Philip M. Hamer (Columbia: University of South Carolina Press, 1992), 513-15 ("9 weeks," "Day Clear"); South Carolina Gazette, 1732-1775, February 14, 1774, South Caroliniana Library ("advantageous Trade"); "Distribution of Presents to the Indians at the Congress, Fort Augusta," November 19, 1763, Jeffery Amherst Papers, vol. 7, William L. Clements Library, University of Michigan, Ann Arbor ("Presents"). 
Bluff Account Books in the Georgia Historical Society provides a glimpse of the trans-Atlantic trade at Silver Bluff, as Creek people traded their deerskins for weapons and ammunition from England, rice and rum from the West Indies, linen from Ireland, tea and spices from India, stones and jewelry from North Africa, and chinaware from Asia. ${ }^{29}$ The Creeks participated in economic networks that stretched from England, Wales, Ireland, Spain, France, and the Dutch Republic to the Holy Roman Empire, Turkey, and India. Also included were West African kingdoms such as Guinea and Senegal, the Atlantic archipelagos of Madeira and the Azores, and the British colonies of New York and Massachusetts. The Creeks thereby invested Silver Bluff with their own commercial meanings, integrating that space into their preexisting economies and reaching out to trans-Atlantic markets and goods. ${ }^{30}$

29. Galphin cemented partnerships with some of the most profitable trading companies for the deerskin trade in Europe and North America, such as Greenwood \& Higginson, John Beswicke \& Co., Clark \& Milligan, Thomas Rock \& Co., Sellars Graham \& Co., and the merchants John McQueen and Henry Laurens, among others.

30. Silver Bluff Trading Post Account Book, 1767-1772, Georgia Historical Society (trans-Atlantic goods); "Entered Inwards, late 1758-1759," Board of Trade and Secretaries of State: America and West Indies, Original Correspondence, Shipping Returns: South Carolina, 1736-1775, Colonial Office (hereafter cited as CO) Record series 5/510, British National Archives, Kew, 64-70 (St. Kitts); "Cleared Outwards, late 1759-1760," CO 5/510, 87-96 (Jamaica); "Cleared Outwards, 1757-1758," CO 5/510, 55-62 (Antigua); "Entered Inwards, early 1762,” CO 5/ 510, 106-14 (Havana); "Entered Outwards, 1756," Board of Trade and Secretaries of State: America and West Indies, Original Correspondence, Shipping Returns: Georgia, 1752-1767, CO 5/709 (Barbados); Peter Leger to Greenwood \& Higginson, March 4,1772, Leger \& Greenwood Letterbook, 1770-1775, 1788, William L. Clements Library, University of Michigan, Ann Arbor, 49 (Vienna); "Entered Inwards, early 1762," CO 5/510, 106-14 (Gibraltar); "Cleared Outwards, late 1759-1760," CO 5/510, 87-96 (Lisbon); Henry Laurens to William Cowles, March 27, 1772, The Papers of Henry Laurens, vol. 8, October 10, 1771-April 19, 1773, ed. David R. Chesnutt and Philip M. Hamer (Columbia: University of South Carolina Press, 1980), 337-38 (“Cowes"); “Cleared Outwards, 1763-early 1764," CO 5/510, 127-36 (Bristol); Journals of the House of Commons, 12th Parliament, 3rd sess., November 15, 1763-April 19, 1764 (London, 1803), 982 (France); "Case of William Greenwood and Willing Higginson," 1772, Records of the Exchequer, October 25, 1772-October 24, 1773, E 134/13Geo3/Mich11, British National Archives, Kew (Amsterdam); "Petition of the Merchants Trading to South Carolina and Georgia to the Lords of the Admiralty," December 18, 1770, Board of Trade and Secretaries of State: America and West Indies, Original Correspondence, Secretary of State: South Carolina, 1730-1784, CO 5/393 (Flanders); Leger and 
The Creeks also endowed Silver Bluff with cultural or cosmological meanings consonant with its status as a white ground connected by a white path to Creek communities. Just as Galphin's plantation operated as a way station for family, politics, and trade, it was also a space of rest, refuge, and renewal for Creek people. Creek micos on long trips to Charleston or Savannah would need somewhere along the way to stop and compose themselves, both before and after negotiations, and they often chose Silver Bluff. In March 1760, when Creek headmen after a "long Conference [at Augusta] resolved to depart with some of their People," they chose to "stay some time with the rest at Mr. Galphin's." While there, Creek leaders could recover from the contentious atmosphere they typically encountered at treaty councils. After the Seven Years' War, Creek leaders most frequently complained about settler encroachments on their lands, which precipitated heated exchanges with imperial agents. As Creek-British negotiations became increasingly antagonistic and characterized by violent verbal confrontations, Creek micos entered the "red" state of mind. At a negotiation's conclusion, the headmen sought to revert to a "white" state of being, but rather than waiting days if not weeks until they returned to their towns, micos instead went to Silver Bluff-a white ground - to renew themselves, purge the red, and reconnect to the white path they were supposed to walk physically and spiritually. ${ }^{31}$

The uncle to Galphin's children, Sempoyaffee, for example, trekked with other Creek micos to Picolata in November 1765 to meet with British authorities who repeatedly expressed their interest in Creek lands in Florida,

Greenwood to London East-India House, December 4, 1773, Board of Trade and Secretaries of State: America and West Indies, Original Correspondence, Secretary of State: East India Co. and Miscellaneous, 1771-1774, CO 5/133 (India); "Entered inwards 1766," CO 5/511, 86-87 (Çadir, Turkey); Charles Garth to His Majesty's Treasury, 1769-1770, "Correspondence of Charles Garth," South Carolina Historical \& Genealogical Magazine 31, no. 2 (1930): 142-43 (“African Trade”); "Petition of Several Merchants in London, Planters of South Carolina, and Owners of Ships Trading to His Majesty's Said Province in America," n.d., 1762-1763, Charles Garth Letterbook, 1758-1760, 1762-1766, William L. Clements Library, University of Michigan, Ann Arbor ("African Isles," Madeira, Canaries); Peter Leger to Greenwood \& Higginson, January 12, 1772, Leger \& Greenwood Letterbook, 1770-1775, 1788, 39 (Senegal); "Petition of Several Merchants in London to the House of Commons," February 22, 1763, Treasury Board Papers and In-Letters, North America: South Carolina, Treasury Records series 1/425/216-217, British National Archives, Kew (Madeira, Canary).

31. Edmond Atkin to William Henry Lyttleton, March 7, 1760, The Letterbooks of William Henry Lyttelton, 1756-1759, box 15. 
despite resistance from Creek micos. While there, a frustrated Sempoyaffee exclaimed, "the white People in Georgia had passed the Line and were settled near Okonie," noting that "if all the Country was settled up to their Towns they would find Nothing by Rats and Rabbits;" he then adamantly refused "to give away any [more] Lands." In his anger, however, Sempoyaffee abandoned the white state of mind for the red one, in which unruly passion and violent words - the hallmark of younger men rather than wise and controlled elder micos- prevailed. In the aftermath of the treaty proceedings, Sempoyaffee departed for "Mr. Galphin's" because Silver Bluff would provide him the space and opportunity to renew himself and return to the white state of mind. This may well be what Galphin was referring to when he wrote to Superintendent Stuart that Creek micos and their entourages always "sett off . . . from my House for the Nation . . . very well Satisfied.” At Silver Bluff, then, Creek people could prepare themselves for treaty negotiations - get in the white mindset-and return to that state after their conferences with imperial authorities. Silver Bluff thus allowed Creeks to restore balance to themselves and their worlds. ${ }^{32}$

The Creeks' multifaceted meanings and uses of Silver Bluff no doubt explain why they mobilized in defense of that place. When Silver Bluff was threatened by French and Cherokee attacks during the Seven Years' War, European observers marveled at how the "Creek Indians ... promise[d] to stand by him [Galphin]" and "scout at some distances round about" Silver Bluff for "[his] protection." And when confirmed reports of attacks in South Carolina reached Charleston in 1761, prompting a flood of "poor People who have taken Shelter" at Silver Bluff, Creek men arrived at Galphin's "Fort, and the People that Way flatter themselves that these Indians will keep off [their] worse Neighbours." These Creeks were accompanied by some of the leading micos for the lower towns, such as Captain Aleck, who “wait[ed] for Intelligence at Mr. Golphin's." Although Europeans assumed the Creeks were defending Galphin and the people he harbored, the Creeks sought to protect that space as much as the man. And again, during the Revolutionary War, the Creeks joined the defense of Silver Bluff. When British forces threatened nearby Augusta and Savannah in early 1776, men from Yuchi and Cusseta mobilized. Although American revolutionaries

32. "Proceedings of the First Picolata Congress," November 15-18, 1765, in Juricek, Early American Indian Documents, 12:454-62 ("Rabbits," "any Lands"); John Stuart to James Grant, March 15, 1769, James Grant of Ballindalloch Papers, 1740-1819, reel 17 ("Land Affairs"); George Galphin to John Stuart, February 19, 1771, in Juricek, Early American Indian Documents, 12:95 ("House," "satisfied"). 
mistakenly believed the "seventy men ... Creek and Euchee Indians" would be "employed in the service of the Province," the Creeks and Yuchis had little interest in the war itself. Despite Galphin's efforts to convince the Creeks and Yuchis to join the revolutionaries, they returned to their towns; they had been at Silver Bluff for one, and only one, reason-its defense. ${ }^{33}$

In rarer instances, Silver Bluff became the target of violence by the Creeks. When Galphin exploited his Native customers or angered Creek micos, they vented their frustrations visibly on the land. In 1773, when Galphin helped imperial authorities engineer the Treaty of Augusta, which ceded nearly three million acres of Creek and Cherokee lands, many of the informal negotiations took place at Silver Bluff between Galphin and lower town micos. Galphin had been so insistent with Creek headmen throughout months of browbeating that they exasperatingly remarked, "they were much tired with the Subject of Land and wanted to have done with it ... [and] proposed to cede to His Majesty as payment of their Debts to the Traders all the Lands." The full extent of the treaty cession had never been fully explained to the Creeks, however, who afterward "were unwilling to submit to so large a demand [of land], and their conduct evidently betrayed a disposition to dispute the ground by force of arms." Thus, in the aftermath of the treaty, a party of Creeks put their "mark upon . . . several trees blazed towards [Silver Bluff], on one of which was an $\mathrm{M}$ with two strokes, and, at a little distance, a bundle of physic." The intent of this message was unmistakable: "no Lands must be given up but Blood for Blood" and the Creeks "blame Mr. Galphin for the whole." ${ }^{4}$

Messages etched into the landscape were deliberate statements whereby the Creeks intentionally severed the white path to Silver Bluff. Since that

33. New York Mercury, February 16, 1760, MS film 245, David Library of the American Revolution ("promise," "scout"); New York Mercury, February 18, 1760 ("stand by," "protection"); Pennsylvania Gazette, April 23, 1761 ("Shelter," "worse Neighbours"); Pennsylvania Gazette, June 6-7, 1760 ("Intelligence”); Colonel Bull to Henry Laurens, March 12, 1776, in R. W. Gibbes, ed., Documentary History of the American Revolution, 1764-1776 (New York: D. Appleton, 1855), 266 ("seventy men," "Euchee," "Province").

34. John Stuart to Thomas Gage, April 24, 1772, in Juricek, Early American Indian Documents, 12:116 ("Subject"); William Bartram, William Bartram on the Southeastern Indians, ed. Gregory A. Waselkov and Kathryn E. Holland Braund (Lincoln: University of Nebraska Press, 1995), 52-53 ("unwilling to submit"); Georgia Gazette, May 25, 1774 (microfilm), University of North Texas, Denton ("blazed"); David Taitt to John Stuart, January 22, 1774, Sir Frederick Haldimand Unpublished Papers, 1758-1784, Add. MS 21672, British Library, London, 164-66 ("Blood," "blame"). 
space had become a site of dispossession, it could no longer serve the purpose of a white ground. Several weeks later, Galphin reached out to the Creeks of Coweta, specifically Escotchaby, to try to restore the white path to Silver Bluff. He confided to Escotchaby, "My Friend, I was very sorry ... [and] I hope all will be made as Straight as ever again." Galphin then asserted, "I am doing all that is in my Power to keep Peace here with your people and the White People and I hope you will do the same there, as you often told me you would do all in your Power to keep Peace between the White People and Indians." Next Galphin promised Escotchaby, "you never shall be poor as long as I live," and he asked the mico, "let me know what you want and I will send it to you"; he concluded with his hopes that "all [will] be made well again." Escotchaby never responded, but fortunately for Galphin, other Creek micos were more forgiving. In April 1777 the Old Tallassee King, Cusseta King, and Handsome Fellow of Okfuskee went to Silver Bluff and delivered "a white fan and a stripe of Beads in token of friendship." They also presented Galphin with a wampum belt and stated, "we may have peace[;] one end of the belt of wampum is the [Creeks] ... and the other end is your house ... which is straight and white." The white ground at Silver Bluff had been restored..$^{35}$

The meanings and uses that the Creeks invested in Silver Bluff illustrate how Native Americans reincorporated colonized spaces into their world. Despite the fact that Europeans like Galphin occupied what were indigenous sites and continually encroached on their other territories, the Creeks did not abandon those spaces. Instead, they continued to interact with the land as they had in the past while reenvisioning its meaning. Silver Bluff took on new life then as a place of family and kinship, cultural and spiritual renewal, mediation and negotiation, and trans-Atlantic exchange, all at the same time. Creek people reinvented Silver Bluff as a white ground, absorbing that colonized space back into their world.

Confronted by the expansion of European empires into their lands, Native Americans not only pushed back but actively assimilated lands already colonized by Euro-Americans. This narrative complicates Western

35. George Galphin to Escotchaby, March 23, 1774, Board of Trade and Secretaries of State: America and West Indies, Original Correspondence, Secretary of State: Indian Affairs, 1763-1784, CO 5/75 ("sorry," "Straight," "Power," "poor," "well again"); "A Talk from the Old Tallassee King and - Mico of the Okfuskee to George Galphin,” April 21, 1777, Benjamin Franklin Papers, pt. 13, Miscellaneous Franklin Materials, 1640-1791, Mss B.F85inventory13, American Philosophical Society, Philadelphia ("white fan," "wampum," "straight and white"). 
understandings of American history and reveals a spatial history of the past that does not simply "fac[e] east from Indian Country," but moves east from Indian Country. As the White Lieutenant of Okfuskee eloquently proclaimed from Silver Bluff in November 1777, "My Land is My Flesh," and he noted that "from old Times our Fathers always reserved these Lands"; he concluded, "I am not alone that Talk about this." ${ }^{36}$

36. Daniel K. Richter; Facing East from Indian Country: A Native History of Early America (Cambridge: Harvard University Press, 2001); "A Treaty of Peace and Commerce," November 6, 1777, George Galphin Letters, 1777-1779 ("Flesh,” "Fathers"). 